\title{
JOURNAL.RU
}

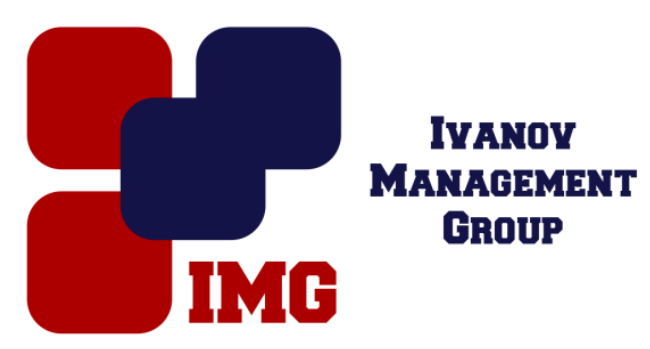

Галушко И. Г., Лопатюк Е.А., Новикова К В.

Кубанский государственный университет Краснодар, Россия

doi: 10.18411/lj-30-06-2017-44

idsp 000001:1j-30-06-2017-44

\section{Основные правила педагогического общения с детьми}

\section{Аннотация}

Жизнь каждого человека практически зависит от общения, которое заложено в основе деятельности людей. Психологический словарь толкует слово "общение" как "взаимодействие двух или более людей, состоящее в обмене между ними информацией познавательного или аффективно-оценочного характера". Гуманистическая психология отдает общению основное, базовое место среди потребностей человека. Лишь благодаря общению люди обмениваются эмоциями и информацией.

Ключевые слова: общение, педагогика, психология, взаимодействие,

Педагогическое общение - это «взаимодействие преподавателя с учащимися в учебно-воспитательном процессе, направленное на создание благоприятного психологического климата, способствующего более полному развитию личности». (Функциями педагогического общения являются познание, обмен информацией, организация деятельности, обмен ролями, сопереживание, самоутверждение).

Процедура общения заключается напрямую в самом акте коммуникации, в котором примут участие общающиеся. При этом обычно их обязано являться двое и более.

Главные основы общения с ребенком:

1. Абсолютное принятие ребенка - исходный положительный подход к детям, согласие со всеми их индивидуальными чертами, минусами, ошибками, 
бедами. Принятие означает проявление терпимости, стремление к пониманию его и помощи.

2. Проявлять уважение к человеку и поддерживать чувство достоинства в каждом.

3. Осознать и признать право личности к стремлению развития индивидуальности, непохожести.

4. Предоставлять право свободного выбора.

5. Оценивать не личность детей, а их деятельность.

6. Владеть способностями к восприятию и пониманию всех людей, уметь видеть проблемы глазами ребенка.

7. Вероятность принимать во внимание индивидуальные психологические характерные для ребенка черты.

Набор основных правил педагогического общения:

- умение к проявлению педагогического такта;

- умение к определению по внешним признакам состояния ребенка; поддерживание мимикой, поза высказывания партнера по общению;

- выслушивание с пониманием и уважением; не иметь привычки прерывать; овладение и развитие культуры речи (доступная, образная, логичная, лаконичная);

- управление при помощи голоса (интонации, дикции);

- управление при помощи мимики, жестов; постараться снизить речь вида монолога в диалоге.

- способности к управлению собственными состояниями и чувствами; настрой на благоприятное восприятие собеседника; овладение приемами развития и применения эмоций тепла, любви, доброжелательности.

Инновационные ресурсы массовой коммуникации поспособствовали появлению новейших течений изучения форм общения различных типов, таких как телефон, телевидение, радио, Интернет и другие. Таким образом, взаимная деятельность опосредована общением.

Только при помощи общения люди вступают во взаимодействия. Подругому, взаимодействие можно назвать интеракцией, по определению это коллективная работа, рассматриваемая со стороны социальной организации. Затрагивая общение, можно сказать, что оно является фактором интеракции. 
Если эти факторы используют в ситуации взаимодействий, то они будут относиться к коммуникативным.

Деятельность актуализирует отношение общества, психологическое содержание процессов общения. И только такой смысл отделяет общение от взаимодействия (интеракции).

Современная наука несет в себе настолько большое количество несовместимых или противоречивых определений и условий - это сильно усложняет исследование и применение на практике элементов общения. Умение общаться является главным критерием эффективной работы по достижению целей в жизни.

$* * *$

1. Бурмистрова, Е. В. Детская возрастная психология // Вестник практической психологии образования. - 2014. - №4. - С. 41 - 44

2. Герасина, Е. В. Детская психология. - М.: Владос, 2010 